Bangladesh J. Plant Taxon. 17(2): 183-191, 2010 (December)

(C) 2010 Bangladesh Association of Plant Taxonomists

\title{
AN ACCOUNT OF THE SPECIES OF LITSEA LAM. (LAURACEAE) ENDEMIC TO INDIA
}

\author{
T. Bhuinya ${ }^{1}$, P. Singh ${ }^{2}$ And SobHan K. MukHerJeE* \\ Taxonomy and Biosystematics Laboratory, Department of Botany, \\ University of Kalyani, Kalyani, Nadia 741 235. W.B., India.
}

Keywords: Litsea; India; Endemic species.

\begin{abstract}
This paper deals with the 18 species of Litsea Lam. endemic to India with special emphasis to the rare elements. Correct nomenclature, brief morphological description, flowering and fruiting period, subject to availability, ecology, distribution and uses, if any, have been provided for each species. The status of the relevant species included in the latest version of IUCN Red List of Threatened Species has also been provided.
\end{abstract}

\section{Introduction}

Lauraceae comprises 52 genera with 2850 species occurring in the warm temperate regions of south-east Asia and Brazil (Mabberley, 1997, 2008). Litsea Lam. belonging to the family Lauraceae consists of more than 300 species in the world (Mabberley, 2008). In India there are 45 species and Litsea species grow in the evergreen or semi-evergreen forests at elevation from 200-3650 m. In the present paper an attempt has been undertaken to assess the number of endemic species of Litsea in India.

\section{Materials and methods}

Field surveys were conducted during 2004 to 2007. Parts of Western Ghats, like the Nilgiri Hills, Trivandrum Hills, Mahabaleshwar Hills and those of Eastern Himalaya like the hills of Darjeeling, Khasi and Jayantia Hills, Garo Hills, hills of Sikkim and foothills of Arunachal Pradesh were explored for Lauraceous flora. This was supplemented with exhaustive literature survey and study of herbarium specimens preserved at Central National Herbarium, Botanical Survey of India, Howrah in West Bengal (CAL), at the herbaria of the different Regional Centres of Botanical Survey of India, namely, Coimbatore in Tamil Nadu (MH), Shillong in Meghalaya (ASSAM), Itanagar in Arunachal Pradesh (ARUN), Pune in Maharashtra (BSI) and those of research institutes and colleges housing good collections of Lauraceous specimens such as St. Xavier's College, Mumbai in Maharashtra (BLAT), Agharkar Research Institute, Pune in Maharshtra (AHMA), Tropical Botanic Garden and Research Institute, Thiruvananthapuram in Kerala (TBGT). Digital images of type specimens were obtained from the Royal Botanic Gardens, Kew (K) to confirm the identity of the species.

*Corresponding author. E- mail: sobhankr@gmail.com; sobhankr@yahoo.com ${ }^{1}$ Central National Herbarium, Botanical Survey of India, Indian Botanic Garden, Shibpur, Howrah-711 103. W.B., India. ${ }^{2}$ Botanical Survey of India, C.G.O. Complex, Salt Lake City, Kolkata-700 064. W.B., India. 
The status of the relevant species included in IUCN Red List of Threatened Species has been given following IUCN (2010), IUCN Red List of Threatened Species. Version 2010.3. <http://www.iucnredlist.org/>.

\section{Results and Discussion}

The species of Litsea Lam. are well distributed in the Indian subcontinent. Out of the 45 species found in the country, 8 show distributions up to China, 12 are found in Nepal, 11 in Bhutan, 6 species show extended distribution to Bangladesh as well as to Myanmar, 4 are found to grow in Sri Lanka and 2 of these species are reported from Pakistan. There are 18 endemic species of Litsea in India and they are distributed in different states (Table 1). Accounts of endemic species of Litsea are given below:

1. Litsea assamica (Meisn.) Hook. f., Fl. Brit. India 5: 161 (1886). [Litsaea]. Tetranthera rangoonensis Meisn. var. assamica Meisn. in DC., Prodr. 15(1): 188 (1864).

Small trees, 5-6 m tall, evergreen; leaves alternate, 2.6-12.2 x 0.9-4.1 cm, highly variable in size, elliptic-ovate; inflorescences umbels, solitary, 4-flowered; fruits berries, 7-9 mm long, ovoid, seated on cup-like perianth tube, cup 5-7 mm in diameter.

Fl.: Feb. - May; Fr.: Mar. - Sept.

Ecology: Grows on low hills of north-eastern India at elevations from 600-1000 m.

Distribution: Arunachal Pradesh, Assam and Meghalaya.

Specimens examined: Arunachal Pradesh, Tirap district, Banfera, G. Panigrahi 16705 (ARUN); Assam, Jenkins s.n. (K); Meghalaya, Khasi Hills, U. Kanjilal 116P (ASSAM).

2. Litsea beddomei Hook. f., Fl. Brit. India. 5: 177 (1886). [Litsaea].

Small trees, 5-8 m tall, evergreen; leaves alternate, 8-10 × 3-4 cm, linear-oblong to linear-lanceolate; inflorescences umbels, arranged in racemes, 4-flowered; fruits berries, 8-12 mm long, ellipsoid, seated on cup-like perianth tube, cup 6-8 $\mathrm{mm}$ in diameter.

Fl.: May - Dec.; Fr.: Sept. - Apr.

Ecology: Grows in evergreen forests of southern Western Ghats at elevation of 800$1300 \mathrm{~m}$.

Distribution: Kerala and Tamil Nadu.

Specimens examined: Kerala, Kannur, Peria, 830 m, V. S. Ramachandran 66868 (MH); Tamil Nadu, Tirunelveli, Beddome s.n. (K) Status: Endangered B1+2c.

3. Litsea bourdillonii Gamble in Bull. Misc. Inform. Kew 1925: 131 (1925).

Medium to large trees, 15-20 m tall, evergreen; leaves alternate, 14-25 x 6-11 cm, elliptic-ovate to oblong-ovate; inflorescences umbels, arranged in sessile clusters, 4flowered; fruits berries, 8-10 mm long, ellipsoid, seated on cup-like perianth tube, cup 4$4.5 \mathrm{~mm}$ in diameter. 
Fl.: Aug. - Mar.; Fr.: Nov. - June.

Ecology: Grows in evergreen and mixed forests of Western Ghats at elevations from 750-1800 m.

Distribution: Karnataka, Kerala and Tamil Nadu.

Specimens examined: Kerala, Thiruvananthapuram, in evergreen forest, $1000 \mathrm{~m}$, Bourdillon 18, 569 (K); Tamil Nadu, Andiparai Shola, 1275 m, Joseph 14210 (CAL).

4. Litsea coriacea (Nees) Hook. f., Fl. Brit. India 5: 166 (1886) [Litsaea]. Tetranthera coriacea Nees in Wall., Pl. Asiat. Rar. 2: 66 (1831).

Small trees, 6-8 m tall, evergreen; leaves alternate, 10-15 x 2.5-5.5 cm, elliptic-ovate to elliptic-lanceolate; inflorescences umbels, arranged in sessile clusters, 4-flowered; fruits berries, 7-15 mm long, ovoid, seated on cup-like perianth tube.

Fl.: Sept. - Jan.; Fr.: Dec. - June.

Ecology: Common in evergreen and mixed forests of Western Ghats at elevations from 900-1500 m.

Distribution: Maharashtra, Karnataka, Kerala and Tamil Nadu.

Specimens examined: Maharashtra: Castle Rock, M. R. Almeida 932 (BLAT); V. D. Vartak s.n. (BSI); V. D. Vartak 13176, 13177 (AHMA); Tamil Nadu, Tirunelveli, Courtallam, Wight 2532 (K).

Uses: Wood is used by the local people for making match boxes, splints and as fuel.

5. Litsea floribunda (Blume) Gamble, Fl. Madras : 1238 (1925). Cylicodaphne floribunda Blume, Mus. Bot. 1: 387 (1852).

Medium to large trees, $12-20 \mathrm{~m}$ tall, evergreen; leaves alternate, $12-20$ x 4-7.5 cm, elliptic-ovate to oblong-ovate; inflorescences umbels, arranged in racemes, 5-6 flowered; fruits berries, 15-17 mm long, ellipsoid, seated on cup-like perianth tube, cup 7-8 $\mathrm{mm}$ in diameter.

Fl.: July - Feb.; Fr.: Sept. - Mar.

Ecology: Common in evergreen and semi-evergreen forests of Western Ghats at elevations from 800-1000 m.

Distribution: Maharashtra, Karnataka, Kerala and Tamil Nadu.

Specimens examined: Maharashtra, Tenmale, Teppakulam, Subramanian 77520 (BSI); Tamil Nadu, Coimbatore, Malinamadursam, Fisher 383 in part; Kerala, Pathanmthitta, Moozhair, 350 m, Anilkumar N. 304 (MH); Karnataka, Garsoppa falls, Talbot 751 (BSI).

6. Litsea ghatica C.J. Saldanha, Fl. Karnataka 1: 67 (1984).

Small trees, 3-5 m tall, evergreen; leaves whorled at apex, alternate below, 9-23.5 x 4-8.5 cm, obovate to oblanceolate; inflorescences umbels, solitary, 6-flowered; fruits 
berries, 7-9 $\mathrm{mm}$ in diameter, globose, seated on plate-like perianth tube, plate 3-4 $\mathrm{mm}$ in diameter.

Fl.: Aug. - Dec.; Fr.: Oct. - Feb.

Ecology: Common in semi-evergreen and evergreen forests at elevations from 500$1000 \mathrm{~m}$.

Distribution: Maharashtra, Karnataka and Kerala.

Specimens examined: Maharashtra, Mahabaleshwar, V. D. Vartak 1167 (AHMA); Karnataka, Shimoga, Kaveledurga, R. Raghavan 82903 (BSI); Kerala, Kannur, Kannoth Reserve forest, 150 m, V. S. Ramachandran 68250 (CAL).

7. Litsea keralana Kosterm. in Ceylon J. Sci., Biol. Sci. 12(2): 138 (1977). L. insignis Gamble in Kew Bull. 1925: 130 (1925), non Boerl. (1900).

Lofty trees, $12-30 \mathrm{~m}$ tall, evergreen; leaves alternate, $15-20 \times 6.5-8 \mathrm{~cm}$, elliptic to obovate; inflorescences umbels, cauliflorous, 12-flowered; fruits berries, 12-16 mm long, ellipsoid, seated on cup-like perianth tube, cup 15-17 mm in diameter.

Fl.: July - Dec.; Fr.: Oct. - Apr.

Ecology: Grows in wet evergreen forests of Western Ghats at elevations from 600$1600 \mathrm{~m}$.

Distribution: Kerala and Tamil Nadu.

Specimens examined: Kerala, Idukki, Triveny, 650 m, B. D. Sharma 42474 (MH); Tamil Nadu, Tirunelveli, Valayar forest, 1600 m, P. Bhargavan 47431 (MH).

8. Litsea laevigata (Nees) Gamble, Fl. Madras : 1236 (1925). Tetranthera attenuata Wall. ex Nees var. laevigata Nees, Syst. Laur. : 677 (1836).

Small trees, 6-8 m tall, evergreen; leaves alternate, 10-18 x 3.5-5.5 cm, oblonglanceolate; inflorescences umbels, arranged in sessile clusters, 4-flowered; fruits berries, 7-15 mm long, ellipsoid, seated on cup-like perianth tube, cup 6-7 mm in diameter.

Fl.: Sept. - Jan.; Fr.: Dec. - June.

Ecology: Grows in evergreen and mixed forests of Western Ghats from 600-1200 m.

Distribution: Karnataka, Kerala and Tamil Nadu.

Specimens examined: Maharashtra, Satara district, Gomantak, V. D. Vartak s.n., (AHMA); Karnataka, Nilkund Ghat, W. A. Talbot (CAL); Kerala, Idukki, Thekkady, 850 m, K. Vivekananthan 46693; Tamil Nadu, Nilgiri, Anamallays, Beddome 122 (CAL).

9. Litsea membranifolia Hook. f., Fl. Brit. India 5: 159 (1886) [Litsaea].

Middle sized trees, 7-10 m tall; leaves alternate, 20-32 x 10-16 cm, oblong-obovate; inflorescences umbels, solitary, 10-12-flowered; fruits not known.

Fl.: June; Fr.: Not known. 
Ecology: Rare in sub-tropical forests of north-east India at elevations from 1000$1200 \mathrm{~m}$.

Distribution: Arunachal Pradesh and Nagaland.

Specimens examined: Arunachal Pradesh, Lower Dibang Valley, Mishmi Hills, Griffith KD 4310 (K); Nagaland, Naga Hills, N. L. Bor 28 (ASSAM).

10. Litsea mishmiensis Hook. f., Fl. Brit. India 5: 161 (1886). [Litsaea].

Large trees, $15-20 \mathrm{~m}$ tall, evergreen; leaves alternate, $10.2-15$ x 3.8-5 cm, oblonglanceolate; inflorescences umbels, solitary, 10-15 flowered; fruits not known.

Fl.: Nov.; Fr.: Not known.

Ecology: Rare in Mishmi Hills in north-east India at elevations from $1250-1300$ m.

Distribution: Arunachal Pradesh.

Specimen examined: Arunachal Pradesh, Lower Dibang Valley, Mishmi Hills, Griffith 4317 (K).

11. Litsea mysorensis Gamble in Kew Bull. 1925: 130 (1925).

Small trees, 5-7 m tall, evergreen; leaves alternate, 8-9.5 x 1.4-2.1 cm, linearlanceolate; inflorescences umbels, arranged in sessile clusters, 4-flowered; fruits not known.

Fl.: Oct. - Feb.; Fr.: Not known.

Ecology: Rare in evergreen and mixed forests of Western Ghats at elevations from 900-1200 m.

Distribution: Kerala, Karnataka and Tamil Nadu.

Specimens examined: Kerala, Kannur, Chandanathode, 840 m, V. S. Ramachandran 66944, 127185, $127186(\mathrm{MH})$.

12. Litsea nigrescens Gamble, Fl. Madras : 1236 (1925).

Moderate sized trees, 10-15 m tall, evergreen; leaves alternate, 11-16 x 4-6 cm, elliptic, black when dry; inflorescences umbels, arranged in racemes; fruits not known.

Fl.: Apr. - May; Fr.: Not known.

Ecology: Rare in evergreen forests of Western Ghats at altitude 600-1200 m.

Distribution: Kerala and Tamil Nadu.

Specimen examined: Kerala, Thiruvananthapuram, Bourdillon 998 (CAL). Status: Endangered B1+2c.

13. Litsea oleoides (Meisn.) Hook. f., Fl. Brit. India 5: 175 (1886). [Litsaea]. Tetranthera oleoides Meisn. in DC., Prodr. 15(1): 195 (1864).

Large trees, 15-30 m tall, evergreen; leaves alternate, opposite on young shoots, $12-$ $20 \times 5-7.5 \mathrm{~cm}$, elliptic-oblong to elliptic-lanceolate; inflorescences umbels, arranged in 
racemes; fruits berries, $2-2.5 \mathrm{~cm}$ in diameter, globose, seated on plate-like perianth tube, plate $10-12 \mathrm{~mm}$ in diameter.

Fl.: Aug. - Dec.; Fr.: Nov. - June.

Ecology: Grows in evergreen forests at elevations from 800-1200 m.

Distribution: Kerala and Tamil Nadu.

Specimens examined: Kerala, Kannur, Chandanathode, 840 m, V. S. Ramachandran 63923 (MH); Tamil Nadu, Nilgiri, Sispara, M. A. Lawson 44727 (MH).

14. Litsea oreophila Hook. f., Fl. Brit. India 5: 156 (1886). [Litsaea].

Small trees, 5-7 m tall, deciduous; leaves alternate, 2.8-3.4 x 1.8-3 cm, elliptic to ovate-lanceolate; inflorescences umbels, solitary or arranged in clusters, 6-flowered; fruits berries, 6-8 $\mathrm{mm}$ in diameter, globose, seated on plate-like perianth tube, plate 2-2.5 $\mathrm{mm}$ in diameter.

Fl.: June - July; Fr.: July - Aug.

Ecology: Rare in Sikkim Himalaya on rocky soil at elevations from $3000-3500$ m.

Distribution: Sikkim.

Specimen examined: Sikkim, Lachoong, 3000-3350 m, Hooker s.n. (K).

15. Litsea stocksii (Meisn.) Hook. f., Fl. Brit. India 5: 176 (1886). [Litsaea]. Tetranthera oblonga Nees var. stocksii Meisn in DC., Prodr. 15(1): 205 (1864).

Medium sized trees, 10-15 m tall, evergreen; leaves alternate, 10-17 x 4-7.5 cm, elliptic-oblong to ovate-lanceolate; inflorescences umbels, arranged in racemes, 6-8 flowered; fruits berries, 7-15 mm long, ellipsoid, seated on cup-like perianth tube, cup 7$10 \mathrm{~mm}$ in diameter.

Fl.: Aug. - Dec.; Fr.: Oct. - Mar.

Ecology: Common in deciduous, semi-evergreen and evergreen forests of Western Ghats at elevations from 900-1300 m.

Distribution: Maharashtra, Karnataka, Kerala and Tamil Nadu.

Specimens examined: Maharashtra, Mahableswar, V. D. Vartak 2163, 2164, 2165 (AHMA); Karnataka, Nellapore, W. A. Talbot 290 (BSI); Kerala, Tirunelveli Reserve Forest, 700 m, V. S. Ramachandran 62106 (MH); Tamil Nadu, Anamalais, C. A. Barber $3970(\mathrm{MH})$.

16. Litsea travancorica Gamble in Kew Bull. 1925: 132 (1925).

Medium sized trees, 7-10 m tall, evergreen; leaves opposite, 14-20 x 5.5-7.5 cm, elliptic-oblong to ovate-oblong; inflorescences umbels, arranged in sessile clusters; fruits berries, 6-10 mm long, ellipsoid, seated on cup-like perianth tube, cup 9-12 $\mathrm{mm}$ in diameter. 
Fl.: Feb. - Mar.; Fr.: Mar. - Apr.

Ecology: Rare in evergreen forests of south Western Ghats at elevations from 900$1200 \mathrm{~m}$.

Distribution: Kerala.

Specimens examined: Kerala, Pathanamthitta, Attathode, E. Vajravelu 80610 (MH, CAL).

Status: Endangered B1+2c.

17. Litsea venulosa (Meisn.) Hook. f., Fl. Brit. India 5: 161 (1886) [Litsaea]. Tetranthera venulosa Meisn. in DC., Prodr. 15(1): 187 (1864).

Straggling shrubs, 5-6 m tall, evergreen; leaves alternate, 8-13 x 2.5-5 cm, ellipticoblong; inflorescences umbels, solitary, 4-5 flowered; fruits berries, 6-10 mm in diameter, globose, seated on plate-like perianth tube, plate 4-5 $\mathrm{mm}$ in diameter.

Fl.: June - Dec.; Fr.: July - Feb.

Ecology: Grows in evergreen and semi-evergreen forests of Western Ghats at elevations 700-1400 m.

Distribution: Kerala and Tamil Nadu.

Specimens examined: Peninsular India Wight s.n. (K); Kerala, Thiruvananthapuram, Agasthamala Hills, Attayar, 700 m, Mohanan TBG\&RI 12439 (TBGT); Tamil Nadu, Lower Nirar to Italiar forest, 950 m, K. Ramamurty 78449 (MH).

18. Litsea wightiana (Nees) Hook. f., Fl. Brit. India 5: 177 (1886) [Litsaea]. Cylicodaphne wightiana Nees in Wall., Pl. Asiat. Rar. 2: 68 (1831).

Large trees, 10-20 m tall, evergreen; leaves alternate, 7-15 x $2.56 \mathrm{~cm}$, elliptic-oblong to oblong-lanceolate; inflorescences umbels, arranged in racemes, 4-6 flowered; fruits berries, 8-12 mm long, ellipsoid, seated on cup-like perianth tube, cup 4-8 $\mathrm{mm}$ in diameter.

Fl.: Aug. - Jan.; Fr.: Oct. - July.

Ecology: Common in evergreen and semi-evergreen forests of Western Ghats at elevations from 1000 - $1800 \mathrm{~m}$.

Distribution: Maharashtra, Goa, Karnataka, Kerala and Tamil Nadu.

Specimens examined: Karnataka, Aglatti, A. Meebold 8479 (CAL); Kerala, Palghat, 725 m, E. Vajravelu 48931 (MH); Tamil Nadu, Kanyakumari, Balamore to M. K. Vayal, 1200 m, A. N. Henry 49399 (CAL).

Uses: Wood is used for making rafters and boats and also as fuel. The resin obtained from the trees is used as a substitute for frankincense. 


\section{Conservation}

The endemic species need to be protected through in situ as well as ex situ conservations. A part of their habitat in south India is included under the Nilgiri Biosphere Reserve. Programmes of ex situ conservation can be undertaken through plant tissue culture, gene banks, etc. Plant taxonomists are urged to collect these species from the existing habitats and spread them to new habitats suitable for their conservation.

Table 1. Occurrence of endemic species of Litsea in different states of India.

\begin{tabular}{|c|c|c|c|c|c|c|c|c|c|c|}
\hline \multirow[t]{2}{*}{ Litsea species } & \multicolumn{10}{|c|}{ States of India having endemic species of Litsea } \\
\hline & AP & $\mathrm{A}$ & $\mathrm{G}$ & $\mathrm{Ka}$ & $\mathrm{K}$ & Ма & $\mathrm{Me}$ & $\mathrm{N}$ & $\mathrm{S}$ & TN \\
\hline L. assamica & + & + & & & & & + & & & \\
\hline L. beddomei & & & & & + & & & & & + \\
\hline L. bourdillonii & & & & + & + & & & & & + \\
\hline L. coriacea & & & & + & + & + & & & & + \\
\hline L. floribunda & & & & + & + & + & & & & + \\
\hline L. ghatica & & & & + & + & + & & & & \\
\hline L. keralana & & & & & + & & & & & + \\
\hline L. laevigata & & & & + & + & & & & & + \\
\hline L. membranifolia & + & & & & & & & + & & \\
\hline L. mishmiensis & + & & & & & & & & & \\
\hline L. mysorensis & & & & + & + & & & & & + \\
\hline L. nigrescens & & & & & + & & & & & + \\
\hline L. oleoides & & & & & + & & & & & + \\
\hline L. oreophila & & & & & & & & & + & \\
\hline L. stocksii & & & & + & + & + & & & & + \\
\hline L. travancorica & & & & & + & & & & & \\
\hline L. venulosa & & & & & + & & & & & + \\
\hline L. wightiana & & & + & + & + & + & & & & + \\
\hline
\end{tabular}

$\mathrm{AP}=$ Arunachal Pradesh, $\mathrm{A}=$ Assam, $\mathrm{G}=\mathrm{Goa}, \mathrm{Ka}=$ Karnataka, $\mathrm{K}=$ Kerala, Ma $=$ Maharashtra, $\mathrm{Me}=$ Meghalaya, $\mathrm{Na}=$ Nagaland, $\mathrm{S}=$ Sikkim, $\mathrm{TN}=$ Tamil Nadu

\section{Conclusion}

Out of the 18 Indian endemic species of Litsea, 4 species i.e. 22\% of the total number of endemic species occur in north-east India and 14 species i.e. $78 \%$ of the total number of endemic species occur in peninsular India including Western Ghats. Among the endemic species of Litsea in India, 3 species are restricted to a very narrow geographical region. L. travancorica is confined to Kerala; L. oreophila in Sikkim and $L$. mishmiensis in Arunachal Pradesh only. Interestingly, one endemic species - L. wightiana is widespread in five different states like Maharashtra, Goa, Karnataka, Kerala and Tamil Nadu. Table-1 provides the distribution of the endemic species of Litsea in Indian states. 
The endemic species of Litsea are confined to 10 states of India. The highest number of endemic species (14) is recorded from Kerala followed by Tamil Nadu (12). The states of Karnataka, Maharashtra and Arunachal Pradesh have 7, 5 and 3 endemic species, respectively. Each of the five states, namely, Assam, Sikkim, Meghalaya, Nagaland and Goa have single endemic species (Table 1).

\section{Acknowledgements}

The authors are thankful to the Director, Botanical Survey of India for his encouragement, to the Curators of the herbaria visited, to the Indian Botanical Liaison Officers, Royal Botanic Gardens, Kew, U.K. for their help and to the Forest Officials for their permission and assistance during field survey, and to the local people for giving the information about the occurrence of the plants during the field surveys. One of the authors (TB) would further like to thank the Director, Botanical Survey of India for awarding the fellowship under the 'Flora of India Project'.

\section{References}

IUCN, 2010. IUCN Red List of Threatened Species. http://www.iucnredlist.org/. IUCN, Gland, Switzerland. Retrieved on 21 September 2010.

Mabberley, D. J. 1997. The Plant Book: A portable dictionary of vascular plants, ed. 2: Cambridge University Press, Cambridge, pp. 393.

Mabberley, D. J. 2008. The Plant Book: A portable dictionary of plants, their classification and uses. Third Edition. Cambridge University Press, Cambridge, pp. 496.

(Manuscript received on 23 September, 2010; revised on 23 November, 2010) 